\title{
Academic Burnout Among University Students During COVID-19 Outbreak
}

\author{
Heni P. Pamungkas ${ }^{1, *}$ Eka I. Nurlaili ${ }^{1}$ \\ ${ }^{1}$ Universitas Negeri Surabaya \\ "Corresponding author.Email: henipamungkas@unesa.ac.id
}

\begin{abstract}
Academic burnout is a well-known concept associated with students' exhaustion during academic life. This study aims to explain factors related to academic burnout during the COVID-19 pandemic. The research method adopted a systematic literature review method to conduct scientific articles indexed by Google Scholar, EBSCO, PubMed, ScienceDirect, and Emerald. Through the screening process, only fifteen articles meet the eligibility criteria. Research results show that university students are prone to experience academic burnout during online learning. Also, there is a different level of academic burnout suffered by students in higher education and senior high school. Some factors that affect academic burnout include work overload, unhealthy lifestyle, social media usage, etc.
\end{abstract}

Keywords: Academic burnout, Literature review, Covid-19 pandemic.

\section{INTRODUCTION}

Burnout syndrome is a well-known concept in the field of psychology. It can be defined as a threedimensional structure, includes exhaustion, cynicism or depersonalization, and the inefficacy or reduction of personal achievement [1]. Specifically, exhaustion includes tension and chronic fatigue. Cynicism includes indifference or alienation toward work, loss of interest in one's work, or belief that work is meaningless. Lack of professional efficacy refers to the decreased ability, achievement, and sense of accomplishment [1].

Burnout syndrome was initially widely known among young people in their careers and was related to job satisfaction. Currently, this concept expanded into another field, not only for professional workers but also in academic life. In terms of academic activities, students are prone to academic burnout. The characteristic of academic burnout is a negative attitude towards education. It is affected by anxiety, which reduces energy and attention that can be used for cognitive tasks. It is a form of exhaustion because of academic requirements[2].

Some inventories are designed to profile someone's level of exhaustion. The commonly used tool is Maslach Burnout Inventory (MBI), which is currently available in four different versions that relate to different topics[3]. Burnout in the MBI General Survey (MBIGS) refers to feelings of overwhelm, tiredness or exhaustion that result from emotionally overwhelming work[4]. Cynicism reflects an indifferent attitude toward work, loss of interest, and the importance of work. Professional effectiveness consists of feelings of competence, success, and achievement in one's job. The lack of professional effectiveness as a dimension of burnout means a loss of the feeling of success or lasting effectiveness at work [5].

Another inventory is Copenhagen Burnout Inventory (CBI). It was formulated as a core construction with fatigue and exhaustion in mind. It consists of 19 questions, and it can be separated into the three components "personal burnout", "professional burnout", and "client-related burnout", the dimensions of professional effectiveness [5].

Due to the Covid-19 pandemic, learning systems worldwide have changed from conventional learning to online learning. However, not all educators have the appropriate skills to teach with IT support. Therefore, not all learning materials can be delivered well. Online learning helps prevent the spread of a pandemic; however, it also has detrimental effects on mental health like depression, anxiety, and stress[6]. Students have been suffering moderate psychological distress since the COVID-19 outbreak in Australia[7]. This unpredictable situation requires another teaching-learning strategy that is suitable for online learning or distance learning.

This is not an easy situation to deal with a pandemic. On the one hand, students are demanded to be active people during the discussion session, do the task, and other academic requirement. On the one hand, low learning recourses barrier their educational process. 
Research conducted revealed that students' stress and anxiety increase because of the Covid-19 pandemic[8]. This research involved 195 university students in Texas; 137 students indicated their stress and anxiety increased during the pandemic.

Furthermore, $89 \%$ of participants had difficulty concentrating on their academic work. Similar findings also found that college students experience moderate depression, anxiety, and stress, suggesting that during quarantine periods [9]. They may be students who lack the essential information technology facilities necessary to meet their academic needs.

According to those explanations, it is interesting to dig deeper into the factor that influences academic burnout among university students because students in higher education are prone to experience academic burnout rather than students in senior or junior high school. Higher education levels impact the highest levels of academic burnout, and students with study time more than 9 hours a day experience the highest academic burnout level[10].

\section{METHODS}

Research questions in this study were:

1. What are the factors that cause academic burnout among university students?

2. How to prevent academic burnout among university students?

This research method used a systematic literature review and followed by some stages.

\subsection{Identification Criteria}

In this stage, the researcher determines the eligibility criteria and keyword phrases during the literature search process. Some eligible criteria were:

a) The type of article is a research article which was written in English and open access

b) The article is indexed by research databases such as EBSCO, Emerald, ScienceDirect, PubMed, and Google Scholar c) Some alternatives keywords during the searching process used several phrases: "academic burnout" or "learning burnout", and "COVID-19 pandemic", and "online learning."

d) Research article examines university student academic burnout

\subsection{Selection Process}

In this stage, researchers reviewed the article based on the title and abstract. The article that is adequate to be reviewed will be included in eligibility studies.

\subsection{Eligibility}

The next step was to screen the articles. However, the other excluded article will not be reviewed further.

All of the stages above will be explained further by the following framework.

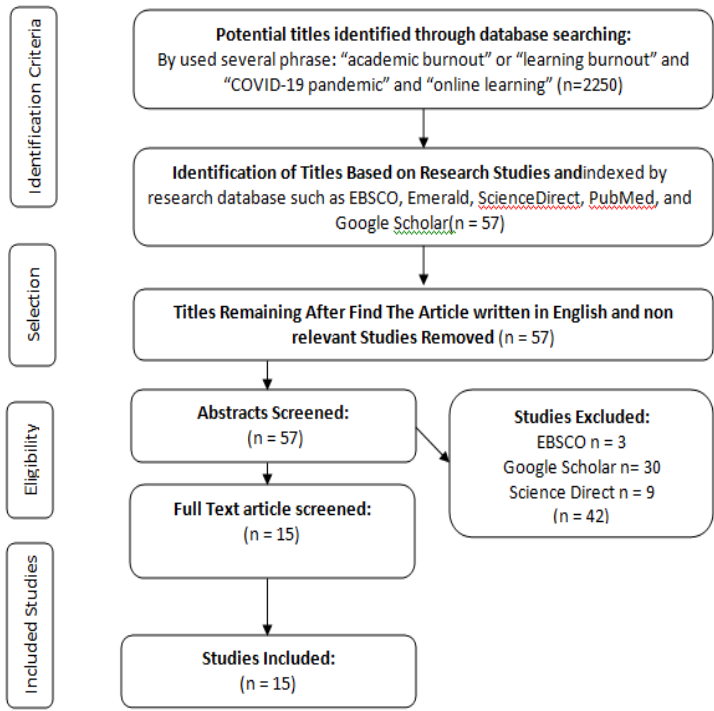

Figure 1. Literature review framework 


\subsection{The Included Studies}

Based on screening stages, there were 15 articles that met the requirement as shown in Table 1.

Table 1. The eligible articles

\begin{tabular}{|c|c|c|c|}
\hline Author & Title & Participant & Result \\
\hline $\begin{array}{l}\text { Žuljević et al. } \\
\text { (2021) }\end{array}$ & $\begin{array}{l}\text { Impact of the first COVID-19 } \\
\text { lockdown on study satisfaction } \\
\text { and burnout in medical students } \\
\text { in Split, Croatia: a cross- } \\
\text { sectional presurvey and } \\
\text { postsurvey }\end{array}$ & $\begin{array}{l}160 \text { paired } \\
\text { responses (before } \\
\text { and after lockdown) }\end{array}$ & $\begin{array}{l}\text { There were no significant differences } \\
\text { in exhaustion between medical } \\
\text { students in two comparison period } \\
\text { (before and after lockdown). }\end{array}$ \\
\hline $\begin{array}{l}\text { Sunawan et al. } \\
(2021)\end{array}$ & $\begin{array}{l}\text { The Differences of Students' } \\
\text { Burnout from Level of } \\
\text { Education and Duration Daily } \\
\text { Online Learning During } \\
\text { COVID-19 Pandemics }\end{array}$ & $\begin{array}{l}2310 \text { students with } \\
\text { different academic } \\
\text { level } \\
\text { Junior High School } \\
\text { students = } 1056 \\
\text { Senior High School } \\
\text { students = 595 } \\
\text { University students } \\
=659\end{array}$ & $\begin{array}{l}\text { Comparing with senior and junior } \\
\text { high school student, university prone } \\
\text { to experience higher levels of } \\
\text { academic exhaustion. }\end{array}$ \\
\hline $\begin{array}{l}\text { Gonzalez-Ramirez } \\
\text { et al. (2021) }\end{array}$ & $\begin{array}{l}\text { Emergency Online Learning: } \\
\text { College Students' Perceptions } \\
\text { during the COVID-19 Crisis }\end{array}$ & 121 & $\begin{array}{l}\text { Freshmen experienced more fatigue } \\
\text { and cynicism compared to } \\
\text { sophomores and juniors. } \\
\text { Furthermore, the results showed that } \\
\text { female students experienced less } \\
\text { cynicism than male students. } \\
\text { Common burdens of college life } \\
\text { include students 'own maturity } \\
\text { transitions, from adjusting in the } \\
\text { freshman year to academic and social } \\
\text { problems as a sophomore or junior, } \\
\text { to seniors' concerns about graduate } \\
\text { plans. }\end{array}$ \\
\hline Koob et al. (2021) & $\begin{array}{l}\text { Factors influencing study } \\
\text { engagement during the COVID- } \\
19 \text { pandemic: A cross-sectional } \\
\text { study among health and social } \\
\text { professions students }\end{array}$ & 559 & $\begin{array}{l}\text { (1) Participation in the study was } \\
\text { positive correlation with student's } \\
\text { social support; } \\
\text { (2) Adequate digital learning is } \\
\text { given positive impact to study } \\
\text { commitment }\end{array}$ \\
\hline Zis et al., (2021) & $\begin{array}{l}\text { Medical Studies during the } \\
\text { COVID-19 Pandemic: The } \\
\text { Impact of Digital Learning on } \\
\text { Medical Students' Burnout and } \\
\text { Mental Health }\end{array}$ & 189 & $\begin{array}{l}\text { The highest rate of burnout was } \\
\text { observed in the last year of medical } \\
\text { studies. There were significantly } \\
\text { fewer fourth-year medical students } \\
\text { who were exhausted during } \\
\text { lockdown period than before } \\
\text { COVID-19. }\end{array}$ \\
\hline Jiang (2021) & $\begin{array}{l}\text { Problematic Social Media } \\
\text { Usage and Anxiety Among } \\
\text { University Students During the } \\
\text { COVID-19 Pandemic: The } \\
\text { Mediating Role of } \\
\text { Psychological Capital and the } \\
\text { Moderating Role of Academic } \\
\text { Burnout }\end{array}$ & 3123 & $\begin{array}{l}\text { Students who feel that their academic } \\
\text { performance affected by the COVID- } \\
19 \text { outbreak, the effects of } \\
\text { problematic social media use and } \\
\text { psychological capital on fear of } \\
\text { academic burnout were moderated. }\end{array}$ \\
\hline
\end{tabular}




\begin{tabular}{|c|c|c|c|}
\hline Naderi et al. (2021) & $\begin{array}{l}\text { Academic burnout among } \\
\text { undergraduate nursing students: } \\
\text { Predicting the role of sleep } \\
\text { quality and healthy lifestyle }\end{array}$ & 143 & $\begin{array}{l}\text { Quality of sleep and healthy } \\
\text { lifestyles predict academic burnout in } \\
\text { nursing students. }\end{array}$ \\
\hline $\begin{array}{l}\text { Moreno-Fernandez } \\
\text { et al. (2020) }\end{array}$ & $\begin{array}{l}\text { Lockdown, Emotional } \\
\text { Intelligence, Academic } \\
\text { Engagement and Burnout in } \\
\text { Pharmacy Students during the } \\
\text { Quarantine }\end{array}$ & 47 & $\begin{array}{l}\text { A total of } 63.5 \% \text { of the students } \\
\text { exhibited academic exhaustion. After } \\
\text { getting emotional intelligence } \\
\text { workshop, only } 31.1 \% \text { showed } \\
\text { academic exhaustion. }\end{array}$ \\
\hline $\begin{array}{l}\text { Tomaszek \& } \\
\text { Muchacka- } \\
\text { Cymerman (2021) }\end{array}$ & $\begin{array}{l}\text { Be Aware of Burnout! The Role } \\
\text { of Changes in Academic } \\
\text { Burnout in Problematic } \\
\text { Facebook Usage among } \\
\text { University Students }\end{array}$ & 115 & $\begin{array}{l}\text { Addiction to use FB is associated } \\
\text { with burnout symptom. }\end{array}$ \\
\hline Zhang et al. (2021) & $\begin{array}{l}\text { Learning Burnout: Evaluating } \\
\text { the Role of Social Support in } \\
\text { Medical Students }\end{array}$ & 315 & $\begin{array}{l}\text { Learning burnout was widespread } \\
\text { among medical students. Senior } \\
\text { students with low family income can } \\
\text { be risk factors for learning } \\
\text { exhaustion. }\end{array}$ \\
\hline $\begin{array}{l}\text { Salgado \& } \mathrm{Au}- \\
\text { Yong-oliveira } \\
(2021)\end{array}$ & $\begin{array}{l}\text { Student Burnout: A Case Study } \\
\text { about a Portuguese Public } \\
\text { University }\end{array}$ & 207 & $\begin{array}{l}\text { Variables associated to burnout: the } \\
\text { professional situation; expectations } \\
\text { of the course; extracurricular } \\
\text { activities participation; the } \\
\text { uncertainty about the professional } \\
\text { future. }\end{array}$ \\
\hline $\begin{array}{l}\text { Kristina et al. } \\
(2020)\end{array}$ & $\begin{array}{l}\text { The effect of role conflict on } \\
\text { academic burnout of } \\
\text { undergraduate Economics } \\
\text { students }\end{array}$ & 114 & $\begin{array}{l}\text { The influence of role conflicts on the } \\
\text { academic burnout of business } \\
\text { students is negligible. This means } \\
\text { that an increase in academic } \\
\text { exhaustion among students is not } \\
\text { determined by role conflicts. Also, } \\
\text { there are many factors related to the } \\
\text { impact on academic burnout, such as } \\
\text { workload, control, reward, } \\
\text { community, fairness, and values. }\end{array}$ \\
\hline $\begin{array}{l}\text { Mahfouz et al. } \\
(2020)\end{array}$ & $\begin{array}{l}\text { Burnout and its associated } \\
\text { factors among } \\
\text { medical students of Jazan } \\
\text { University, Jazan, } \\
\text { Saudi Arabia }\end{array}$ & 440 & $\begin{array}{l}\text { Burnout syndrome was widespread } \\
\text { among Jazan University medical } \\
\text { students. In the present study, several } \\
\text { factors were identified that are } \\
\text { associated with burnout. }\end{array}$ \\
\hline Im \& Lee (2021) & $\begin{array}{l}\text { A study of the relationship } \\
\text { between learning flow and } \\
\text { learning burnout in college } \\
\text { online classes }\end{array}$ & 149 & $\begin{array}{l}\text { Students with higher learning flow } \\
\text { showed less learning exhaustion. }\end{array}$ \\
\hline $\begin{array}{l}\text { de la Fuente et al. } \\
(2021)\end{array}$ & $\begin{array}{l}\text { How Has the COVID-19 Crisis } \\
\text { Affected the Academic Stress } \\
\text { of University Students? The } \\
\text { Role of Teachers and Students }\end{array}$ & 642 & $\begin{array}{l}\text { Studying during pandemic did not } \\
\text { have a significant impact on the } \\
\text { stress induced by the teaching } \\
\text { process. }\end{array}$ \\
\hline
\end{tabular}




\section{RESULTS AND DISCUSSION}

\subsection{Factors Associated with Academic Burnout}

The academic syndrome is a phenomenon that was established long ago and is still relevant until this era. Some studies tried to compare students' academic burnout before and during the COVID-19 pandemic. However, there are no significant differences in academic burnout levels before and during pandemics [11]. The same findings revealed showed that there is no significant difference in the general predominant of burnout among medical students in the two periods (before and during the pandemic) [14].

Although there are no significant differences in the academic burnout level between the two periods, students with different levels of education will experience a different level of academic burnout. University students experienced higher academic burnout levels than secondary school students[10]. This has a similar result if there is a significantly different level between freshman and sophomore. First-year students are statistically more exhausted and cynical than sophomores and juniors[12]. Sophomores and juniors were chosen as the benchmark category because first-year students and seniors have undergone different changes. Furthermore, the results showed that, on average, female students were less cynic than male students. Common pressures in college include the transition of students' maturity, from first-year adjustments to sophomores and social issues to seniors' students' worries about post-graduation plans.

Other factors associated with academic burnout are students' uncertainty about their future, participation in extracurricular activities, physical activity frequency, course expectations, and academic requirements. Moreover, workload, control, reward, community, fairness, and values are affecting students' academic burnout, too[20]. Therefore, students' academic burnout affected their academic performance, such as missing the classes, not completing assignments correctly, decreasing academic achievement, not even completing undergraduate studies, or dropping out of university.

Another factor related to exposure to social media networks of academic burnout was found[15]. A similar finding also revealed the interaction effects between social motives on Facebook and changes in academic burnout and between the importance of Facebook and its inefficiency and burnout[17].

An unhealthy lifestyle also causes academic burnout. The quality of sleep and a healthier lifestyle can predict academic exhaustion. Students whose good quality of sleep and implement a healthy lifestyle have a slight chance to experience academic burnout.
Based on the discussion above, it can be concluded that several factors affect academic fatigue in students, including:

1. Education level in college

2. Student participation in learning

3. Student social environment

4. The use of social media by students

5. Student lifestyle

\subsection{Academic Burnout Prevention}

Academic burnout is a common condition suffered by students which are caused by overload work or academic demand. It is also influenced by student social environment and students' lifestyles. This situation can be prevented through the following options [24]:

a) Increasing awareness about stress and academic burnout, which is due to the increasing of telecommunication usage during pandemics

b) Take more break time between online learning. Thus students can reduce eye strain and avoid loss of focus and learning interest.

c) Instruct students to develop health exercises to make them aware of physical and emotional consequences due to the increase of online time.

d) Introduce podcast-based communication and learning to replace visual communication online. It helps to reduce screen exposure and eye strain.

e) Implement a healthy, active lifestyle

f) Reducing unhealthy habits which can increase stress levels.

\section{CONCLUSION}

Academic burnout can be suffered by everyone who attends formal education. It drives to serious matters such as losing learning motivation, exhaustion, low academic achievement, and so on. The Covid-19 outbreak was also influenced by the duration someone interacted in an online class or meeting. Students who engage with online classes for long hours a day tend to have higher academic burnout than students who have less interaction[10]. To prevent this inconvenient condition, educators and students can take some preventive action, such as: do icebreaking or relaxing activities during break time, reducing on-screen time to avoid eye strain, and implementing a healthy, active lifestyle.

\section{REFERENCES}

[1] C. Maslach and M. P. Leiter, "Understanding the burnout experience: Recent research and its implications for psychiatry," World Psychiatry, vol. 15 , no. 2, pp. 103-111, 2016, DOI: 10.1002/wps.20311.

[2] H. Naderi, H. Dehghan, S. Dehrouyeh, and E. Tajik, 
"Academic burnout among undergraduate nursing students: Predicting the role of sleep quality and healthy lifestyle," pp. 12-17, 2021, DOI: 10.34172/rdme.2021.016.

[3] J. Maroco and J. A. D. B. Campos, "Defining the student burnout construct: A structural analysis from three burnout inventories," Psychol. Rep., vol. 111, no. 3, pp. 814-830, 2012, DOI: 10.2466/14.10.20.PR0.111.6.814-830.

[4] J. A. D. B. Campos, M. S. Carlotto, and J. Marôco, "Copenhagen burnout inventory - student version: Adaptation and transcultural validation for Portugal and Brazil," Psicol. Reflex. e Crit., vol. 26, no. 1, pp. 87-97, 2013, doi: 10.1590/S010279722013000100010.

[5] S. Toppinen-Tanner, Process of Burnout: Structure, Antecedent and Consequences, vol. 93. 2011.

[6] N. H. Al-Rawi et al., "Prevalence of Burnout among Dental Students during COVID-19 Lockdown in UAE," J. Contemp. Dent. Pract., vol. 22, no. 5, pp. 538-544, 2021, DOI: 10.5005/jp-journals-100243072 .

[7] Z. Lyons, H. Wilcox, L. Leung, and O. Dearsley, "COVID-19 and the mental well-being of Australian medical students: impact, concerns and coping strategies used," Australas. Psychiatry, vol. 28, no. 6, pp. 649-652, 2020, DOI: $10.1177 / 1039856220947945$.

[8] C. Son, S. Hegde, A. Smith, X. Wang, and F. Sasangohar, "Effects of COVID-19 on college students' mental health in the United States: Interview survey study," J. Med. Internet Res., vol. 22, no. 9, 2020, DOI: 10.2196/21279.

[9] S. H. Hamaideh, H. Al-Modallal, M. Tanash, and A. Hamdan-Mansour, "Depression, anxiety and stress among undergraduate students during COVID-19 outbreak and 'home-quarantine,", Nurs. Open, no. January, pp. 1-9, 2021, DOI: 10.1002/nop2.918.

[10] S. Sunawan, Z. N. Amin, A. Hafina, and M. I. Kholili, "The Differences of Students ' Burnout from Level of Education and Duration Daily Online Learning During COVID-19 Pandemics,” pp. 37233729, 2021.

[11] M. F. Žuljević, K. Jeličić, M. Viđak, V. Đogaš, and I. Buljan, "Impact of the first COVID-19 lockdown on study satisfaction and burnout in medical students in Split, Croatia: a cross-sectional presurvey and post-survey," BMJ Open, vol. 11, no. 6, p. e049590, 2021, DOI: 10.1136/bmjopen-2021049590 .

[12] J. Gonzalez-Ramirez et al., "Emergency Online
Learning: College Students' Perceptions during the COVID-19 Crisis," SSRN Electron. J., pp. 29-47, 2021, DOI: $10.2139 /$ ssrn.3831526.

[13] C. Koob, K. Schröpfer, M. Coenen, S. Kus, and N. Schmidt, "Factors influencing study engagement during the COVID-19 pandemic: A cross-sectional study among health and social professions students," PLoS One, vol. 16, no. 7, p. e0255191, 2021, DOI: 10.1371/journal.pone.0255191.

[14] P. Zis, A. Artemiadis, P. Bargiotas, A. Nteveros, and G. M. Hadjigeorgiou, "Medical studies during the COVID-19 pandemic: The impact of digital learning on medical students' Burnout and mental health," Int. J. Environ. Res. Public Health, vol. 18, no. 1, pp. 1-9, 2021, DOI: 10.3390/ijerph18010349.

[15] Y. Jiang, "Problematic Social Media Usage and Anxiety Among University Students During the COVID-19 Pandemic: The Mediating Role of Psychological Capital and the Moderating Role of Academic Burnout," Front. Psychol., vol. 12, no. December 2020, pp. 1-12, 2021, DOI: 10.3389/fpsyg.2021.612007.

[16] J. Moreno-Fernandez et al., "Lockdown, Emotional Intelligence, Academic Engagement and Burnout in Pharmacy Students during the Quarantine," Pharmacy, vol. 8, no. 4, p. 194, 2020, DOI: 10.3390/pharmacy8040194.

[17] K. Tomaszek and A. Muchacka-Cymerman, "Be Aware of Burnout! The Role of Changes in Academic Burnout in Problematic Facebook Usage among University Students," Int. J. Environ. Res. Public Health, vol. 18, no. 15, p. 8055, 2021, DOI: 10.3390/ijerph18158055.

[18] J. Y. Zhang, T. Shu, M. Xiang, and Z. C. Feng, "Learning Burnout: Evaluating the Role of Social Support in Medical Students," Front. Psychol., vol. 12, pp. 1-14, 2021, DOI: 10.3389/fpsyg.2021.625506.

[19] S. Salgado and M. Au-Yong-oliveira, "Student burnout: A case study about a portuguese public university," Educ. Sci., vol. 11, no. 1, pp. 1-35, 2021, doi: 10.3390/educsci11010031.

[20] A. D. Kristina, J. T. L. Loekmono, and S. Setyorini, "The effect of role conflict on academic burnout of undergraduate Economics students," Int. J. Res. Couns. Educ., vol. 4, no. 2, p. 98, 2020, DOI: 10.24036/00333za0002.

[21] M. S. Mahfouz et al., "Burnout and its associated factors among medical students of Jazan University, Jazan, Saudi Arabia,” Ment. Illn., vol. 12, no. 2, pp. 35-42, 2020, doi: 10.1108/MIJ-06-2020-0011. 
[22] H. I'm and Y. L. Lee, "A Study of Relationship Between Learning Flow and Learning Burnout in College Online Classes," J. Digit. Converg., vol. 19, no. 6, pp. 39-46, 2021.

[23] J. de la Fuente et al., "How Has the COVID-19 Crisis Affected the Academic Stress of University Students? The Role of Teachers and Students," Front. Psychol., vol. 12, no. June, pp. 1-16, 2021, DOI: $10.3389 /$ fpsyg.2021.626340.

[24] N. Mheidly, M. Y. Fares, and J. Fares, "Coping With Stress and Burnout Associated With Telecommunication and Online Learning," Front. Public Heal., vol. 8, no. November, 2020, DOI: 10.3389/fpubh.2020.574969. 